\title{
PENCAPAIAN KINERJA MELALUI RESPONSIFITAS PADA PESAING DENGAN MODERASI TENSI PERSAINGAN DAN KELONGGARAN SUMBERDAYA
}

\author{
Muslich Anshori (slich@feb.unair.ac.id) \\ Badri Munir Sukoco (badri_unair@yahoo.com) \\ Mikhael Mangihot Napitupulu \\ Fakultas Ekonomi dan Bisnis Universitas Airlangga
}

\begin{abstract}
Telecommunication industry in Indonesia is growing rapidly in the last two decades. Prepaid services remain dominant (above 90\%), in which 95\% are distributed electronically. The condition attracts many players to participate in the business and eventually increasing the competitive tension among them. Based on market orientation perspective, we investigate whether responsiveness toward competitors deliver higher performance for electronic server company? Moreover, this study address under which conditions that the relationship is strengthened or weakened? By distributing questionnaires among all electronic server companies in Surabaya, we reported that responsiveness toward competitors positively contribute to companies' performance. The relationship strengthened when the slack resources was low than high, while there was no moderating effect of competitive tension. Managerial and academic implications are further discussed.
\end{abstract}

Keywords: responsiveness to competitors, competitive tension, slack resources, financial performance, and telecommunication industry

\section{PENDAHULUAN}

Industri telekomunikasi di Indonesia dalam 1 dekade terakhir sangat dinamis. Sejak diluncurkannya UU no. 36 tahun 1999 tentang telekomunikasi, semakin banyak provider layanan telekomunikasi yang beroperasi dan menawarkan produknya ke konsumen Indonesia. Ditunjang oleh populasi yang sangat besar dan pertumbuhan ekonomi yang relatif stabil, jumlah pengguna layanan telekomunikasi - terutama telepon seluler, meningkat pesat. Berdasarkan data ClA (2012), pengguna telepon seluler Indonesia terbesar nomor lima sedunia dengan jumlah sebesar 220 juta. Hingga saat ini terdapat 8 provider telekomunikasi, dimana tiga pemain lama (Telkomsel, Indosat, dan Excelcomindo) masih menjadi trio penguasa pasar. Dari data yang dikeluarkan oleh Kementerian Komunikasi dan Informasi (2012), pengguna telepon seluler pasca bayar mempunyai proporsi yang relatif kecil $(3,87$ juta jiwa atau setara dengan 2,43\%) dibandingkan pengguna telepon pra bayar pada tahun 2009. Pengguna layanan pasca bayar relatif susah untuk dipersuasi, sehingga pasar yang sangat besar untuk pengguna layanan pra bayar menjadi arena pertarungan yang sengit antar provider.

Selama ini, lebih dari 80\% layanan pra bayar didistribusikan oleh distributor dan agen pulsa. Kompetisi tinggi juga terjadi antar penyedia pulsa elektrik yang memiliki market share layanan pra bayar lebih dari 95\%, sisanya berupa layanan pra bayar secara fisik. Perusahaan distributor pulsa elektrik adalah perusahaan yang bergerak dalam bidang pendistribusian pulsa secara eletronik. Menurut ASPINDO (Asosiasi Server Pulsa Indonesia), saat ini baru terdapat 304 perusahaan yang terdaftar, dan masih banyak perusahaan serupa yang belum terdaftar ataupun belum mendaftar. Besarnya pasar yang ada, 3 triliun rupiah per bulan, dan banyaknya perusahaan yang menyediakan layanan tersebut menjadikan persaingan yang ada di dalam industry pendistribusian pulsa secara eletrik terjadi secara intens. Tentunya patut diinvestigasi apakah responsifitas pada tindakan pesaing tersebut menunjang kinerja perusahaan? Menggunakan konsep orientasi pasar 
(Jaworski dan Kohli, 1990), penelitian ini mencoba menjawabnya. Meta analysis yang dilakukan oleh Kirca, Jayachandran, dan Bearden (2005) dengan menggunakan 114 studi memperlihatkan adanya variasi pengaruh orientasi pasar terhadap kinerja keuangan perusahaan, dengan rentang antara $-0,130$ hingga 0,460. Adapun pengaruh orientasi pasar terhadap kinerja pemasaran perusahaan mempunyai rentang antara 0,140 hingga 0,580. Hasil ini menimbulkan pertanyaan kapan pengaruh orientasi pasar dalam hal ini responsifitas pada pesaing terhadap kinerja perusahaan dapat diperkuat atau diperlemah?

Guna menjawab pertanyaan tersebut, penelitian ini mengajukan dua variabel yang mungkin dapat memoderasi pengaruh orientasi pasar terhadap kinerja perusahaan. Yang pertama adalah slack resources (kelonggaran sumberdaya - Nohria dan Gulati, 1996; Sharfman, Wolf, Chase, dan Tansik, 1988).) sebagai faktor internal perusahaan, dan yang kedua adalah competitive tension (tensi persaingan - Chen, Su, dan Tsai, 2007) sebagai faktor antar perusahaan. Responsifitas pada pesaing tentunya membutuhkan dukungan sumberdaya yang cukup, dan keberadaan sumberdaya yang longgar tentunya memberikan amunisi yang memadai bagi sebuah perusahaan dalam memberikan respon terhadap pesaingnya (Voss, Sirdeshmukh, dan Voss, 2008). Logika inilah yang memungkinkan responsifitas pada pesaing memiliki pengaruh yang berbeda terhadap kinerja perusahaan bilamana perusahaan memiliki kelonggaran sumberdaya yang berbeda.

Mengadopsi pendapat dari Chen dkk. (2007), perusahaan merespon tindakan pesaing dengan tingkatan yang berbeda dan tergantung pada seberapa tinggi persepsi mereka terhadap tensi persaingan yang mereka rasakan. Semakin tinggi persaingan yang dirasakan oleh sebuah perusahaan, semakin besar kemungkinan bagi mereka untuk merespon tindakan yang dilakukan oleh pesaing. Berdasarkan logika tersebut, tentunya patut diinvestigasi apakah merespon tindakan pesaing yang memiliki tensi persaingan yang tinggi akan menghasilkan kinerja yang lebih tinggi atau justru sebaliknya.

Penelitian ini juga mengadopsi pendapat dari Voss dkk. (2008) bahwa keberadaan sumberdaya yang longgar tentunya memberikan amunisi yang memadai bagi sebuah perusahaan dalam memberikan respon terhadap pesaingnya. Bilamana ketersediaan sumberdaya mencukupi, tentunya perusahaan tersebut akan dapat merespon tindakan pesaing dengan cepat dan sesuai dengan volume atau frekuensi tindakan pesaing. Yang menjadi pertanyaan adalah apakah ketersediaan sumberdaya tersebut akan memperkuat atau memperlemah pengaruh respon pada pesaing terhadap kinerja perusahaan. Ketiga pertanyaan tersebut akan diinvestigasi melalui penelitian ini.

\section{LANDASAN TEORI DAN PENGEMBANGAN HIPOTESIS}

\section{Responsifitas terhadap Pesaing}

Respon yang cepat terhadap perubahan lingkungan merupakan faktor yang penting bagi kesuksesan perusahaan. Pada saat meningkatnya persaingan dan terus berkembangnya kebutuhan pelanggan, tanggapan terhadap perubahan lingkungan telah menjadi faktor yang penting bagi kesuksesan perusahaan. White, Varadarajan, dan Dacin (2003, hal 63) menyatakan untuk bertahan hidup dan berkembang di pasar yang kompetitif, organisasi atau perusahaan harus berusaha terus-menerus merespon peluang dan ancaman yang ditimbukan oleh perubahan lingkungan. faktor terutama yang berlaku untuk perubahan berkaitan dengan dua kelompok kunci dalam lingkungan perusahaan: pelanggan dan pesaing. Penelitian sebelumnya pada bidang pemasaran telah menunjukan bahwa respon yang terkait dengan perubahan pelanggan dan pesaing memiliki konsekuensi yang bermanfaat bagi beberapa perusahaan (misalnya Gatignon, Robertson, and Fein 1997; Jayachandran, Hewett, and Kaufman 2004; Smith, Bolton, and Wagner 1999; Smith et al. 1989).

Pada penelitian ini lebih difokuskan kepada respon perusahaan terhadap pesaing. Sebagaimanana sebuah organisasi atau perusahaan merespon dengan cepat perubahan 
yang dilakukan oleh pesaing yang terkait. Intensitas kompetitif mengacu pada tingkat persaingan dalam suatu pasar (Kohli and Jaworski 1990). Lingkungan pasar dengan persaingan yang kuat biasanya ditandai dengan tekanan lebih besar pada harga, tingkat tinggi iklan, kuat produk dan persaingan teknologi (Porter 1980). Pada lingkungan tersebut perusahaan dan manajer memiliki sedikit waktu untuk bereaksi terhadap pesaing yang bergerak (Kumar, Subramanian, and Yauger 1998). Sehingga manajer kekurangan waktu untuk melakukan analisis terhadap situasi dan harus mengaandalkan intuitif penilaian keadaan. Dalam situasi yang ditandai dengan tekanan waktu yang tinggi dampak relatif dari sistem afektif pada respon pesaing terkait meningkat. Pada saat yang sama efektivitas dari sistem kognitif sebagai respon penggerak berkurang ketika intensitas kompetitif tinggi. Lebih spesifik, pada lingkungan seperti itu kemampuan menganalisa kompetitif menurun (Maltz and Kohli 1996, p. 52) yang dapat mengurangi reliabilitas informasi yang diberikan oleh sistem kognitif. Selain itu menjadi lebih sulit untuk mendapatkan informasi pesaing terkait yang relevan (Slater and Narver 1994). Akibatnya seperti Baum and Wally (2003) berpendapat, membuat keputusan menghabiskan waktu lebih sedikit dibandingkan dengan riset yang membosankan terhadap pesaing karena mereka mendapatkan sedikit keuntungan.

\section{Tensi Persaingan}

Persepsi tensi persaingan didefinisikan oleh Chen dk. (2007) sebagai sejauh mana para manajer sebuah perusahaan mempertimbangkan perusahaan rival sebagai kompetitor utama yang mendorong tindakan yang dilakukan (hal. 103). Hal ini tentunya berbeda dengan tensi obyektif yang dihasilkan karena perubahan struktur industri atau kondisi pasar dimana para rival bersaing, dikenal dengan kesamaan pasar (Chen, 1996), persinggungan di beberapa pasar - multimarket contacts (Baum dan Korn, 1999), atau ancaman yang timbale balik - reciprocal threat (Gimeno (1999). Penggunaan istilah tensi dirasa lebih tepat dalam menggambarkan kondisi tingkat persaingan yang dirasakan oleh sebuah perusahaan sebelum mengambil tindakan yang kompetitif (Chen dkk., 2007). Hal inilah yang menjadikan hubungan persaingan yang cenderung statis dalam persaingan obyektif menjadi lebih dinamis sesuai dengan konsep persaingan yang dinamis (Chen, 2006). Bilamana tensi persaingan yang terbangun telah mencukupi, maka tindakan kompetitif akan dapat terprediksikan.

Persepsi tensi persaingan hampir sama dengan konsep rivalitas psikologis yang diajukan oleh Kilduff, Elfenbein, dan Staw (2010), yakni persaingan yang dirasakan sebuah perusahaan terhadap rival utamanya. Persepsi yang dirasakan oleh para manajer sebuah perusahaan akan meningkatkan keterlibatan secara psikologis dan pertaruhan yang akan dilakukan dari persaingan yang ada, terlepas dari fakta obyektif di lapangan (Chen dkk., 2007). Semakin tinggi tensi persaingan yang dipersepsikan, tindakan para manajer di sebuah perusahaan akan dapat diprediksikan (Dutton dan Jackson, 1987; Reger dan Huff, 1993).

\section{Kelonggaran Sumberdaya}

Kelonggaran sumberdaya (slack resources) merupakan kelebihan sumberdaya yang tersimpan dan tersedia bagi organisasi dalam sebuah periode waktu tertentu (Nohria \& Gulati, 1996; Sharfman dkk., 1988). Kelonggaran sumberdaya merupakan hasil dari kinerja organisasi sebelumnya, atau sengaja dijadikan cadangan, atau karena perencanaan yang kurang matang. Mengingat definisi tersebut mengimplikasikan bahwa kelonggaran sumberdaya yang dimiliki perusahaan cukup beragam, maka Voss dkk., (2008) menawarkan solusi dengan mengajukan dua dimensi utama dalam mengkategorikannya, yakni kelangkaan (rarity) dan penyerapan (absorption) dari sumberdaya yang dimaksud. Berdasarkan konsep resources-based view (Barney, 1991), kelangkaan dan keunikan sebuah sumberdaya akan menentukan keberlanjutan keunggulan kompetitif sebuah organisasi di pasar. Sumberdaya alam atau SDM dengan keahlian tertentu mungkin langka dikarenakan ketersediaannya terbatas di pasar. Sumberdaya lain yang dapat dikumpulkan namun 
membutuhkan upaya yang keras dan waktu yang lama dengan proses yang kompleks, misalnya social capital yang terakumulasi melalui waktu yang lama dan proses sosial yang kompleks (Barney \& Hansen, 1994). Penyerapan sumberdaya juga bervariasi tingkatannya, dan sumberdaya yang tidak terserap akan lebih mudah untuk dialokasikan bagi organisasi (Sharfman et al., 1988; Tan \& Peng, 2003). Ketersediaan dana tunai atau kredit yang belum digunakan akan mudah dialokasikan untuk kepentingan organisasi, sedangkan keberadaan sumberdaya spesialis yang tidak terdayagunakan sulit untuk dimanfaatkan organisasi (Greve, 2003).

Voss dkk. (2008) menggunakan kedua dimensi tersebut untuk mengkategorikan slack resources menjadi 4 jenis. Pertama adalah sumberdaya yang memiliki kelangkaan dan penyerapan yang rendah, yakni kelonggaran keuangan. Sumberdaya ini bisa dicari dari internal maupun eksternal perusahaan dan cukup mudah untuk digunakan dalam operasional perusahaan tanpa proses yang lama (Kraatz dan Zajac, 2001). Yang kedua adalah sumberdaya dengan kelangkaan yang tinggi namun penyerapannya rendah, yakni kelonggaran hubungan dengan pelanggan. Komitmen yang tinggi dari pelanggan tentunya membutuhkan waktu lama untuk membangunnya (Adler dan Kwon, 2002), namun organisasi akan mudah memanfaatkannya untuk membujuk mereka menggunakan produk lain yang dihasilkan. Yang ketiga adalah sumberdaya dengan kelangkaan yang rendah namun penyerapannya tinggi, yakni kelonggaran operasional. Kelebihan dari kapasitas operasional organisasi dapat dengan mudah dicari, namun cukup sulit dialokasikan ke divisi atau bagian lain karena spesifikasi yang tidak sama (Tan dan Peng, 2003). Yang terakhir adalah sumberdaya dengan kelangkaan dan penyerapan yang tinggi, yakni kelonggaran sumberdaya manusia. Sumberdaya manusia yang terspesialisasi jarang didapat di pasar dengan mudah (Mishina dkk., 2004), dan pada saat yang sama tidak setiap saat mereka dapat dimanfaatkan untuk kepentingan organisasi karena kekhususan yang mereka miliki. Penelitian ini mengkhususkan pada kelonggaran sumberdaya jenis pertama, mengingat semua perusahaan penjual pulsa elektronik memilikinya dan ketiga jenis yang lain relative sama satu sama lain.

\section{Pengembangan Hipotesis}

Perusahaan cenderung akan bertindak agresif terhadap perusahaan-perusahaan lainnya yang memasuki pasar atau dianggap mengancam pasar yang dianggap vital (Smith ef al,1991) dan telah meneliti dampak dari persaingan multimarket untuk langkah memasuki pasar (Baum \& Korn, 1996) dan harga (Gimeno, 1999). Penelitian juga telah menunjukan bahwa manajer maupun outside stakeholder membuat penilaian kompetitif yang serupa (Chen, Farh, \& MacMillan, 1993) dan bahwa penilaian seperti itu dapat memprediksi tindakan yang diambil oleh pesaing di dalam suatu industri (Chen \& MacMillan, 1992).

$H_{1}$ : Responsifitas terhadap pesaing utama mempunyai pengaruh positif terhadap kinerja (a) pemasaran dan (b) keuangan perusahaan.

Penelitian menunjukkan bahwa hasil yang didapatkan lebih tinggi secara signifikan dari perusahaan yang berada pada kondisi persaingan yang sulit dibandingkan yang berada pada kondisi persaingan yang mudah (Brehm, Wright, Soloman, Silka, \& Greenberg, 1983). Rivalitas antara pesaing secara positif terkait dengan daya saing bersejarah pertarungan mereka sehingga dapat meningkatkan tensi persaingan yang dirasakan dan meningkatkan kinerja penjualan. Oleh karena itu dapat diprediksi bahwa perusahaan yang memiliki sejarah daya saing berimbang bertemu akan memiliki persaingan yang kuat, meningkatkan Tensi Persaingan yang dirasakan antar perusahaan, dan saling meningkatkan kinerja perusahaan.

$\mathrm{H}_{2}$ : $\quad$ Pengaruh responsifitas terhadap pesaing utama akan semakin menguat terhadap kinerja (a) pemasaran dan (b) keuangan perusahaan apabila tensi persaingan yang dipersepsikan tinggi dibandingkan rendah.

Peluang dan ancaman mengacu pada penilaian persepsi manajerial dari sejauh mana lingkungan operasional dari organisasi atau perusahaan menjanjikan keuntungan 
dibandingkan dengan kerugian (Staw, Sandelands, \& Dutton, 1981). Prospek teori dan hipotesis mengenai ancaman dan kekakuan menyebabkan argumen yang bertentangan tentang efek kesempatan dan ancaman lingkungan (cf. Chattopadhyay, Glick, \& Huber, 2001; Fiegenbaum \& Thomas, 1988). Organisasi dengan slack resources kemungkinan menanggapi ancaman melalui peningkatan pengambilan resiko, sejalan dengan prediksi teori prospek, untuk melakukancounter atau meminimalkan efek dari aspek yang mengancam lingkungan, organisasi harus berinvestasi. Namun lingkungan yang mengancam dikombinasikan dengan slack yang dibatasi secara struktural dapat meningkatkan perasaan kurangnya kontrol, sebagai akibatnya, organisasi harus melakukan tanggapan kaku, penghematan dan keengganan untuk beresiko. Dutton and Duncan (1987) menyarankan, organisasi dihadapkan dengan situasi yang memerlukan respon yang mendesak tetapi kurang sumberdaya yang diperlukan cenderung mengadopsi perubahan incremental sebagai sarana untuk mengatasi, bukan melawan.

$H_{3}$ : $\quad$ Pengaruh responsifitas terhadap pesaing utama akan semakin menguat terhadap kinerja (a) pemasaran dan (b) keuangan perusahaan apabila slack resources rendah dibandingkan tinggi.

\section{METODE PENELITIAN}

Peneliti menggunakan 6 item yang dikembangkan oleh Homburg dkk. (2007) guna mengukur responsifitas terhadap pesaing. Untuk faktor ketegangan persaingan diukur menggunakan 6 item yang dikembangkan berdasarkan konsep rivalitas psikologis (Kilduff dkk., 2010). Sedangkan kinerja pemasaran perusahaan menggunakan 6 item yang dikembangkan oleh Homburg dan Pflesser (2000) dan Homburg dkk. (2007), adapun 3 item yang mengukur kinerja keuangan perusahaan dari Hult, Ketchen, dan Slater (2005). Item yang mengukur responsifitas terhadap pesaing dan kinerja perusahaan menggunakan 7 skala Likert, sedangkan item yang mengukur ketegangan persaingan menggunakan 5 skala Likert. Kelonggaran sumberdaya menggunakan skala kategorikal, dimana 1 menunjukkan kelonggaran sumberdaya yang tinggi dan 0 menunjukkan sebaliknya.

Penggunaan skala yang berbeda (yaitu 5 dan 7 skala Likert) dilakukan sebagai salah satu cara untuk mengurangi efek self-generated validity (Feldman dan Lynch, 1988) berdasarkan saran dari Podsakoff, Mackenzie, Lee, dan Podsakoff (2003). Penelitian ini juga melakukan balancing order, yakni mengurutkan pertanyaan tidak secara berurutan (misalnya, kinerja perusahaan diletakkan di awal, diikuti oleh kelonggaran sumberdaya, kemudian ketegangan persaingan).

Peneliti mendistribusikan kuesioner kepada semua perusahaan server pulsa di Surabaya (43 perusahaan). Perusahaan tersebut telah mendistribusikan pulsa elektrik minimal 2 tahun terakhir kepada seluruh operator telekomunikasi. Berikut adalah informasi demografis dari responden: Terdapat 27 responden laki-laki (64,30\%), rentang usia antara 26-35 tahun mempunyai proporsi yang dominan $(59,5 \%)$, diikuti lebih dari 36 tahun $(31,00 \%)$. Sebagian besar responden adalah pemilik dan manajer $(54,80 \%)$, sisanya adalah SDM yang menghandle operasional perusahaan sehari-hari. Lebih dari $70 \%$ memiliki masa kerja diatas 3 tahun, dengan jenjang pendidikan sarjana juga memiliki prosentase yang sama $(71,40 \%)$.

\section{HASIL DAN PEMBAHASAN}

Peneliti menggunakan Confirmatory Factor Analysis (CFA) dan menemukan bahwa hampir semua factor loading dan korelasi mempunyai nilai lebih tinggi dari 0,600, dan setiap dimensi atau faktor yang digunakan mempunyai eigen-value lebih dari 1. Sedangkan semua nilai Cronbach's a mempunyai nilai lebih dari 0,700 (Tabel 1). Untuk menguji discriminant validity, peneliti menggunakan 2 langkah:

Pertama, menggunakan uji Harman's one-factor test dengan menempatkan semua item pertanyaan dalam principal component factor analysis (Podsakoff dan Organ, 1988). Hasilnya menunjukkan bahwa tidak ada satu faktor yang mendominasi (terdapat 6 faktor 
yang dihasilkan dengan $75,992 \%$ adalah total variance, dan factor pertama mempunyai $27,115 \%$ variance).

Kedua, uji perbedaan $\chi^{2}$ dilakukan untuk masing-masing pasangan dari faktor yang ada, dan semuanya menunjukkan bahwa masing-masing faktor memang berbeda secara signifikan, yang lebih lanjut menunjukkan bahwa masing-masing faktor tidaklah collinear (Anderson dan Gerbing, 1988), sehingga discriminant validity diantara masing-masing konstruk penelitian telah dikonfirmasi. Matriks korelasi juga menunjukkan bahwa hipotesis yang diajukan memang tervalidasi (Tabel 2).

Untuk menguji hipotesis, penelitian ini menggunakan regresi linear berganda. Hasil regresi linier berjenjang seperti pada Tabel-3. Dari pengujian hipotesis tersebut diperoleh hasil sebagai berikut: Hipotesis-1 menyatakan bahwa responsifitas terhadap pesaing utama mempunyai pengaruh positif terhadap kinerja (a) pemasaran dan (b) keuangan perusahaan. Hasil analisa menunjukkan bahwa pengaruh positif responsifitas terhadap pesaing utama berpengaruh positif dan signifikan terhadap kinerja pemasaran ( $\beta=0,412$, $p$ $<0,05)$ maupun keuangan perusahaan $(\beta=0,420, \mathrm{p}<0,05)$, sehingga hasil ini mendukung $\mathrm{H}_{1}$ yang telah diajukan.

Tabel 1. Analisa Validitas dan Reliabilitas

\begin{tabular}{|c|c|c|c|c|c|c|}
\hline Kode & Pertanyaan & $\begin{array}{l}\text { Factor } \\
\text { Loading }\end{array}$ & $\begin{array}{l}\text { Eigen- } \\
\text { Value }\end{array}$ & $\begin{array}{c}\% \text { of } \\
\text { Variance }\end{array}$ & $\begin{array}{l}\text { Item-total } \\
\text { correlation }\end{array}$ & $\begin{array}{c}\text { Cronbach } \\
\text { Alpha }\end{array}$ \\
\hline \multicolumn{7}{|c|}{ Responsifitas terhadap Pesaing (Homburg dkk., 2007) } \\
\hline RP1 & $\begin{array}{l}\text { Perusahaan Anda dengan } \\
\text { cepat menanggapi } \\
\text { perubahan harga yang } \\
\text { dilakukan oleh pesaing } \\
\text { terkuat }\end{array}$ & 0.801 & 2.254 & 56.345 & 0.559 & 0.720 \\
\hline RP2 & $\begin{array}{l}\text { Perusahaan Anda dengan } \\
\text { cepat menanggapi } \\
\text { perubahan kualitas produk } \\
\text { yang dilakukan oleh pesaing } \\
\text { terkuat }\end{array}$ & 0.860 & & & 0.644 & \\
\hline RP3 & $\begin{array}{l}\text { Perusahaan Anda dengan } \\
\text { cepat menanggapi } \\
\text { perubahan/penambahan } \\
\text { fasilitas yang dilakukan oleh } \\
\text { pesaing terkuat }\end{array}$ & 0.500 & & & 0.508 & \\
\hline RP4 & $\begin{array}{l}\text { Perusahaan Anda dengan } \\
\text { cepat menanggapi } \\
\text { perubahan strategi } \\
\text { pemasaran yang dilakukan } \\
\text { oleh pesaing terkuat }\end{array}$ & 0.789 & & & 0.562 & \\
\hline RP5 & $\begin{array}{l}\text { Server pesaing terkuat } \\
\text { merupakan fokus dari semua } \\
\text { aktivitas perusahaan Anda } \\
\text { baik dari sisi produk ataupun } \\
\text { pemasaran }\end{array}$ & & & & & \\
\hline RP6 & $\begin{array}{l}\text { Strategi perusahaan Anda } \\
\text { berdasarkan pada strategi } \\
\text { dari pesaing terkuat }\end{array}$ & & & & & \\
\hline
\end{tabular}


Tabel 1. Analisa Validitas dan Reliabilitas (Lanjutan)

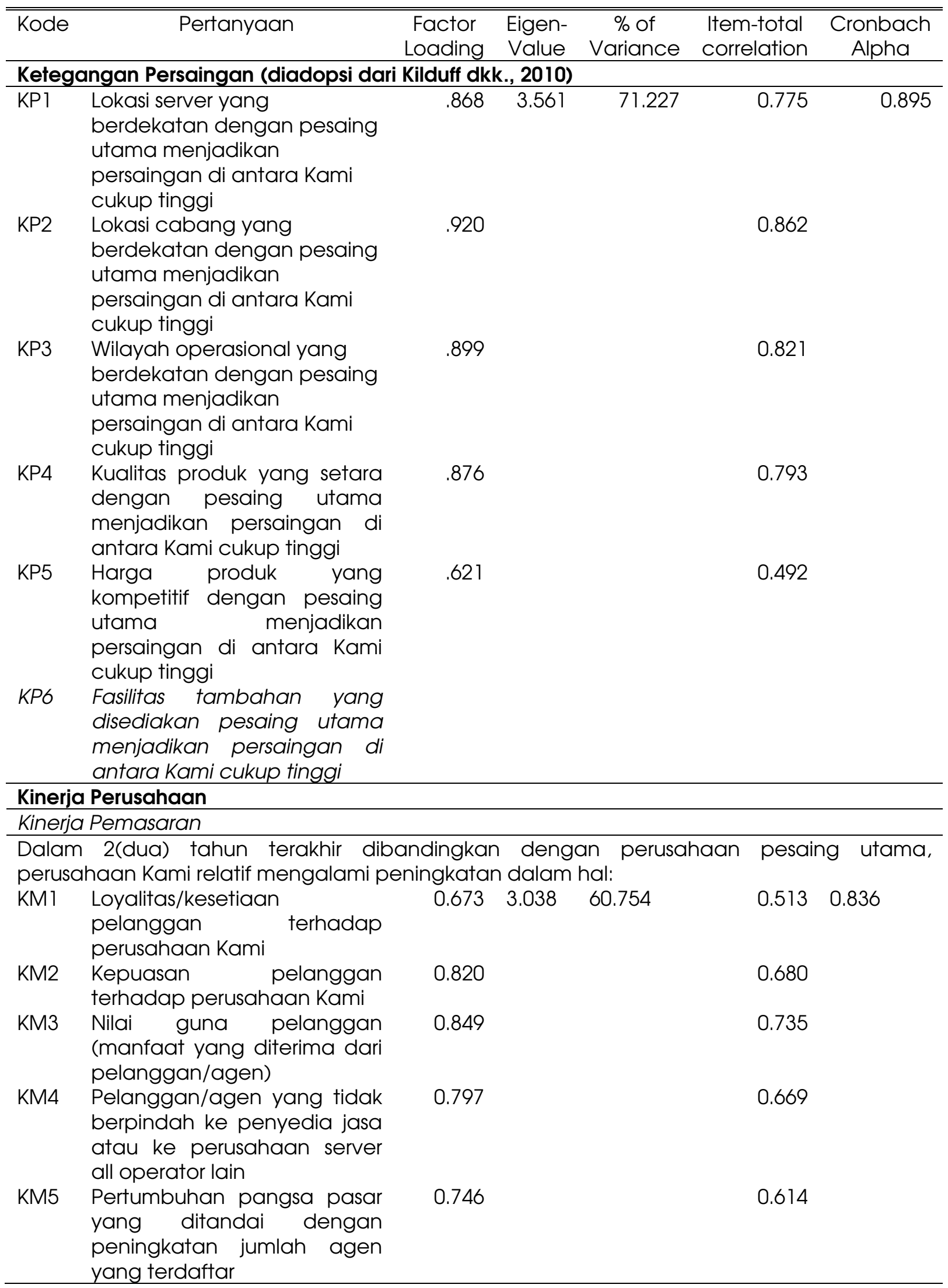


Tabel 1. Analisa Validitas dan Reliabilitas (Lanjutan)

\begin{tabular}{|c|c|c|c|c|c|c|}
\hline Kode & Pertanyaan & $\begin{array}{l}\text { Factor } \\
\text { Loading }\end{array}$ & $\begin{array}{l}\text { Eigen- } \\
\text { Value }\end{array}$ & $\begin{array}{c}\% \text { of } \\
\text { Variance }\end{array}$ & $\begin{array}{l}\text { Item-total } \\
\text { correlation }\end{array}$ & $\begin{array}{l}\text { Cronbach } \\
\text { Alpha }\end{array}$ \\
\hline \multicolumn{7}{|c|}{ Kinerja Perusahaan } \\
\hline \multicolumn{7}{|c|}{ Kinerja Pemasaran } \\
\hline \multirow{2}{*}{$\begin{array}{l}\text { Dalam } \\
\text { perusc } \\
\text { KM1 }\end{array}$} & $\begin{array}{l}\text { 2(dua) tahun terakhir dib } \\
\text { haan Kami relatif mengalami } \mathrm{pe}\end{array}$ & $\begin{array}{l}\text { andingkar } \\
\text { ningkatar }\end{array}$ & $\begin{array}{l}\text { deng } \\
\text { dalam }\end{array}$ & $\begin{array}{l}\text { xn perus } \\
\text { hal: }\end{array}$ & רaan pesai & ig utama, \\
\hline & $\begin{array}{l}\text { Loyalitas/kesetiaan } \\
\text { pelanggan } \\
\text { perusahaan Kami }\end{array}$ & 0.673 & 3.038 & 60.754 & 0.513 & 0.836 \\
\hline KM2 & $\begin{array}{l}\text { Kepuasan pelanggan } \\
\text { terhadap perusahaan Kami }\end{array}$ & 0.820 & & & 0.680 & \\
\hline KM3 & $\begin{array}{l}\text { Nilai guna pelanggan } \\
\text { (manfaat yang diterima dari } \\
\text { pelanggan/agen) }\end{array}$ & 0.849 & & & 0.735 & \\
\hline KM4 & $\begin{array}{l}\text { Pelanggan/agen yang tidak } \\
\text { berpindah ke penyedia jasa } \\
\text { atau ke perusahaan server } \\
\text { all operator lain }\end{array}$ & 0.797 & & & 0.669 & \\
\hline KM5 & $\begin{array}{l}\text { Pertumbuhan pangsa pasar } \\
\text { yang ditandai dengan } \\
\text { peningkatan jumlah agen } \\
\text { yang terdaftar }\end{array}$ & 0.746 & & & 0.614 & \\
\hline \multicolumn{7}{|c|}{ Kinerja Keuangan } \\
\hline KK1 & $\begin{array}{lr}\text { Pertumbuhan } & \text { penjualan } \\
\text { yang ditandai } & \text { dengan } \\
\text { meningkatnya } & \text { transaksi } \\
\text { pembelian pulsa } & \end{array}$ & 0.794 & 1.980 & 66.011 & 0.544 & 0.739 \\
\hline KK2 & $\begin{array}{l}\text { Pengurangan biaya yang } \\
\text { dikeluarkan dalam proses } \\
\text { penjualan produk }\end{array}$ & 0.831 & & & 0.593 & \\
\hline KK3 & $\begin{array}{l}\text { Laba/keuntungan } \\
\text { investasi perusahaan }\end{array}$ & 0.812 & & & 0.566 & \\
\hline
\end{tabular}

Catatan: Item yang tercetak miring dihapus karena factor loadingnya kurang dari 0,500.

Untuk menguji efek moderasi yang diajukan pada hipotesis kedua dan ketiga, peneliti menggunakan regresi berjenjang, mengingat variabel bebas dan moderatornya merupakan variabel continuous. Menurut Aiken dan West (1991) dan Cohen, Cohen, West, dan Aiken (2003), penggunaan regresi berjenjang mampu mempertahankan sifat kontinyu dari sebuah variabel tanpa kehilangan informasi atau menurunkan kekuatan untuk mendeteksi efek moderasi. Mengingat variabel-variabel tersebut mempunyai multikolinearitas yang tinggi, maka peneliti menggunakan metode centering seperti yang disarankan oleh Frazier, Tix dan Barron (2004).

Tabel 2. Analisa Deskriptif dan Matriks Korelasi

\begin{tabular}{|c|c|c|c|c|c|c|c|c|c|c|c|c|c|c|c|}
\hline Variabel & Mean & S.D. & 1 & 2 & 3 & 4 & 5 & 6 & 7 & 8 & 9 & 10 & 11 & 12 & 13 \\
\hline Gender & 1.357 & 0.485 & 1.000 & & & & & & & & & & & & \\
\hline Umur & 2.214 & 0.606 & $-0.350^{\circ}$ & 1.000 & & & & & & & & & & & \\
\hline Psisi & 2.190 & 1.254 & $0.728^{* *}$ & $-0.376^{\circ}$ & 1.000 & & & & & & & & & & \\
\hline Umur & 3.286 & 0.835 & -0.138 & $0.310^{*}$ & 0.017 & 1.000 & & & & & & & & & \\
\hline
\end{tabular}




\begin{tabular}{|c|c|c|c|c|c|c|c|c|c|c|c|c|c|c|c|}
\hline perusahaan & & & & & & & & & & & & & & & \\
\hline Omzet & 1.902 & 1.158 & 0.021 & -0.004 & 0.308 & 0.235 & 1.000 & & & & & & & & \\
\hline $\begin{array}{l}\text { Jumlah } \\
\text { karyawan }\end{array}$ & 1.762 & 0.431 & -0.050 & 0.107 & 0.086 & 0.126 & 0.051 & 1.000 & & & & & & & \\
\hline $\begin{array}{l}\text { Jumlah } \\
\text { cabang }\end{array}$ & 3.024 & 1.294 & 0.065 & 0.058 & -0.080 & -0.098 & $-0.441^{*}$ & $0.322^{*}$ & 1.000 & & & & & & \\
\hline $\begin{array}{l}\text { Lama } \\
\text { persaingan } \\
\text { Responsifitas }\end{array}$ & 1.690 & 0.468 & -0.038 & 0.240 & -0.063 & 0.294 & 0.034 & 0.230 & 0.180 & 1.000 & & & & & \\
\hline $\begin{array}{l}\text { terhadap } \\
\text { pesaing }\end{array}$ & 3.786 & 0.373 & 0.063 & 0.019 & 0.037 & 0.123 & $0.323^{\circ}$ & 0.206 & 0.076 & -0.005 & 1.000 & & & & \\
\hline $\begin{array}{l}\text { Tensi } \\
\text { persaingan }\end{array}$ & 5.077 & 1.073 & 0.110 & 0.143 & 0.129 & 0.050 & 0.199 & 0.080 & -0.073 & -0.158 & 0.218 & 1.000 & & & \\
\hline $\begin{array}{l}\text { Kelonggaran } \\
\text { sumberdaya }\end{array}$ & 1.667 & 0.477 & 0.211 & 0.169 & $0.313^{*}$ & 0.245 & 0.253 & $0.316^{*}$ & 0.175 & 0.291 & 0.069 & 0.230 & 1.000 & & \\
\hline $\begin{array}{l}\text { Kinerja } \\
\text { pemasaran }\end{array}$ & 3.786 & 0.531 & 0.162 & 0.070 & 0.301 & 0.086 & 0.287 & -0.122 & -0.122 & 0.021 & 0.163 & 0.222 & 0.048 & 1.000 & \\
\hline $\begin{array}{l}\text { Kinerja } \\
\text { keuangan }\end{array}$ & 3.821 & 0.453 & 0.020 & -0.035 & 0.104 & 0.074 & 0.178 & -0.161 & 0.050 & -0.152 & $0.400^{* *}$ & 0.261 & 0.000 & $0.572 *$ & 1.00 \\
\hline
\end{tabular}

Hipotesis-2 memprediksi bahwa pengaruh positif responsifitas terhadap pesaing utama akan semakin menguat terhadap kinerja perusahaan bila tensi persaingan yang dipersepsikan tinggi. Hasil analisa menunjukkan bahwa tidak ada pengaruh moderasi yang signifikan pada pengaruh responsifitas pada pesaing utama terhadap kinerja pemasaran $(\beta=-0,114, p=$ 0,489 ) maupun keuangan perusahaan $\left(\beta=0,178, p=0,336\right.$ ), sehingga $\mathrm{H}_{2 a}$ dan $\mathrm{H}_{2 b}$ tidak dapat diterima.

Hipotesis-3 memprediksi bahwa pengaruh positif responsifitas terhadap pesaing utama akan melemah terhadap kinerja perusahaan bila slack resources tinggi. Hasil analisa menunjukkan bahwa pengaruh moderasi yang diajukan hanya terbukti pada pengaruh responsifitas pada pesaing utama terhadap kinerja pemasaran perusahaan ( $\beta=-1,049, p<$ $0,013)$, sedangkan pada kinerja keuangan tidak signifikan $(\beta=0,274, p=0,603)$, sehingga hanya $\mathrm{H}_{3 a}$ yang dapat diterima. 
Tabel 3. Regresi Linear Berjenjang

\begin{tabular}{|c|c|c|c|c|c|c|c|c|}
\hline \multirow{3}{*}{ Variabel Penelitian } & \multicolumn{8}{|c|}{ Variabel Dependen } \\
\hline & \multicolumn{4}{|c|}{ Kinerja Pemasaran } & \multicolumn{4}{|c|}{ Kinerja Keuangan } \\
\hline & M1 & $\mathrm{M} 2$ & M3 & M4 & M5 & M6 & M7 & M8 \\
\hline \multicolumn{9}{|l|}{ Variabel Kontrol } \\
\hline Gender & -0.344 & $-0.464^{*}$ & $-0.452^{+}$ & $-0.398^{*}$ & -0.114 & -0.236 & -0.312 & -0.243 \\
\hline Umur & $0.449^{*}$ & $0.469^{* *}$ & $0.431^{*}$ & $0.499^{* *}$ & -0.003 & 0.018 & -0.013 & 0.024 \\
\hline Jabatan & 0.254 & 0.386 & 0.345 & $0.392^{+}$ & 0.164 & 0.299 & 0.358 & 0.319 \\
\hline Umur perusahaan & 0.020 & -0.016 & -0.016 & 0.008 & 0.099 & 0.061 & 0.078 & 0.061 \\
\hline Penjualan & 0.170 & -0.035 & -0.036 & 0.086 & 0.267 & 0.058 & -0.007 & 0.051 \\
\hline Jumlah pegawai & -0.198 & -0.263 & $-0.293^{+}$ & $-0.281+$ & -0.281 & -0.347 & -0.340 & $-0.332+$ \\
\hline Jumlah cabang & 0.044 & -0.046 & -0.067 & -0.055 & 0.304 & 0.212 & 0.248 & 0.233 \\
\hline $\begin{array}{l}\text { Pengalaman bersaing } \\
\text { Efek Utama }\end{array}$ & -0.180 & -0.139 & -0.100 & 0.010 & -0.157 & -0.115 & -0.103 & -0.138 \\
\hline $\begin{array}{l}\text { Responsifitas terhadap } \\
\text { pesaing (RtP) }\end{array}$ & & $0.412^{*}$ & $0.344^{*}$ & $1.366^{* *}$ & & $0.420^{*}$ & $0.452^{*}$ & 0.160 \\
\hline Tensi persaingan (TP) & & & 0.133 & & & & 0.222 & \\
\hline $\begin{array}{l}\text { Kelonggaran sumberdaya } \\
\text { (KS) }\end{array}$ & & & & -0.248 & & & & -0.013 \\
\hline \multicolumn{9}{|l|}{ Efek Interaksi } \\
\hline$R+P \times T P$ & & & -0.114 & & & & 0.178 & \\
\hline $\mathrm{R}+\mathrm{P} \times \mathrm{KS}$ & & & & $-1.049^{*}$ & & & & 0.274 \\
\hline $\mathrm{R}^{2}$ & 0.333 & 0.465 & 0.489 & 0.597 & 0.159 & 0.296 & 0.360 & 0.303 \\
\hline$\Delta R^{2}$ & & 0.131 & 0.009 & 0.101 & & 0.137 & 0.022 & 0.007 \\
\hline$\Delta \mathrm{F}$ & 1.937 & 7.354 & 0.491 & 7.034 & 0.733 & 5.826 & 0.957 & 0.277 \\
\hline Sig & 0.090 & 0.011 & 0.489 & 0.013 & 0.662 & 0.022 & 0.336 & 0.603 \\
\hline
\end{tabular}

Catatan: + signifikan pada $p>0.10$, "signifikan pada $p>0.10$, "signifikan pada p>0.10, **signifikan pada $p>0.10$,

Menggunakan prosedur dari Aiken dan West (1991) dan Cohen dkk. (2003), peneliti menggambarkan efek moderasi tersebut (Gambar 1). Kinerja pemasaran akan mencapai titik tertinggi ( $\bar{X}=5,376$ ) ketika perusahaan memiliki responsifitas terhadap pesaing utama tinggi, namun pada saat yang sama mereka memiliki slack resources yang rendah. Bilamana mereka memiliki slack resources yang rendah, kinerja pemasaran yang dimiliki perusahaan memiliki nilai yang lebih rendah $(\bar{X}=4,126)$ meskipun mereka memiliki responsifitas terhadap pesaing cukup tinggi. Tingkatan kinerja yang hampir sama juga terjadi ketika perusahaan memiliki slack resources yang tinggi namun responsifitas terhadap epsaing utama cukup rendah $(\bar{X}=4,054)$. Kinerja terendah terjadi ketika perusahaan memiliki responsifitas pada pesaing yang cukup rendah dan pada saat yang sama mereka memiliki slack resources yang tinggi $(\bar{X}=2,804)$. 
Gambar 1 - Efek Moderasi Slack Resources

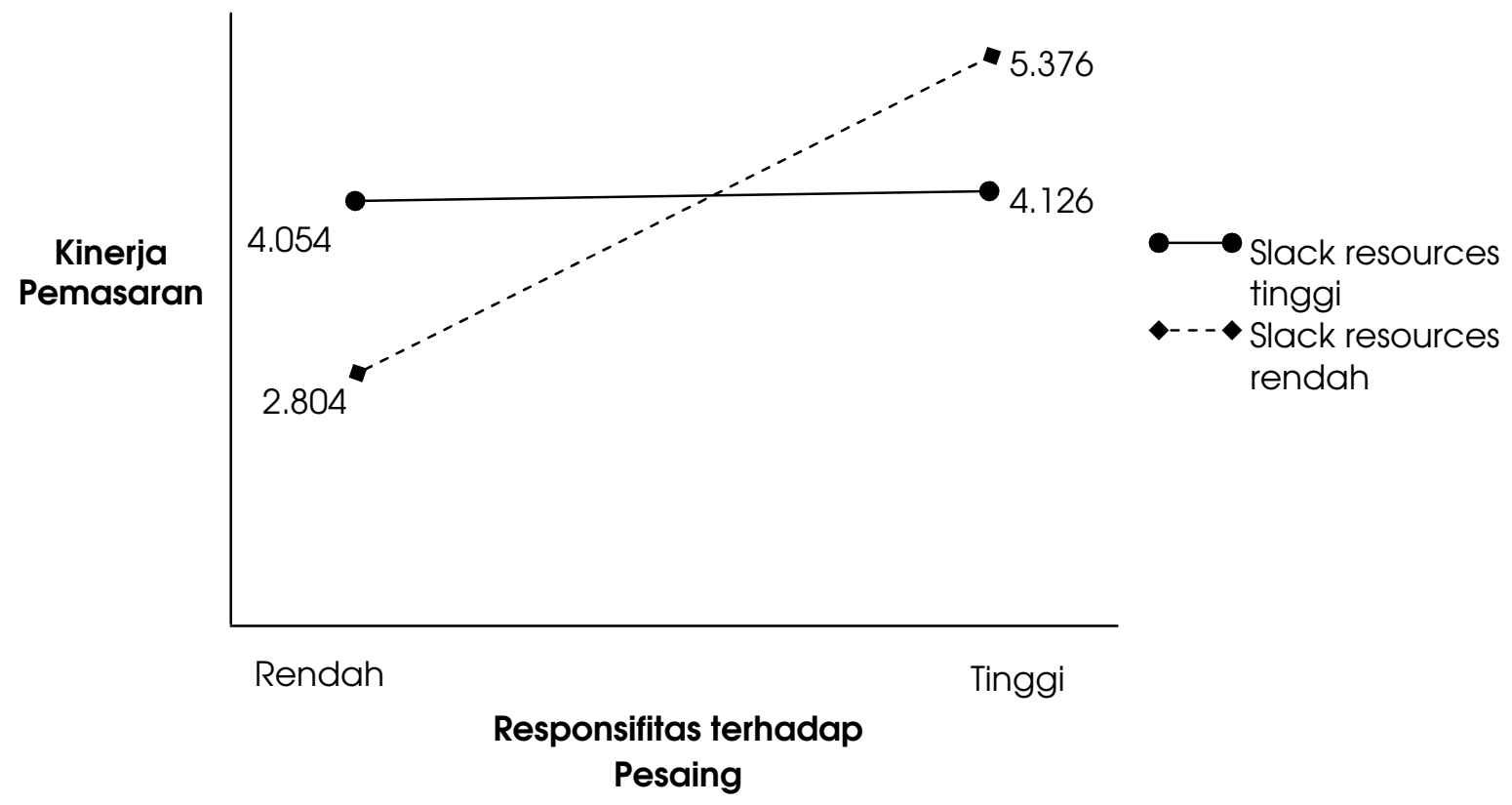

\section{SIMPULAN}

Berdasarkan hasil pengolahan data dalam penelitian ini, dapat ditarik kesimpulan sebagai berikut: Pertama, responsifitas terhadap pesaing berpengaruh secara signifikan baik terhadap kinerja pemasaran maupun terhadap kinerja keuangan. Hal ini berarti dalam penelitian ini perusahaan cenderung akan bertindak agresif terhadap perusahaanperusahaan lainnya yang memasuki pasar atau dianggap mengancam pasar yang dianggap vital, dan perusahaan akan fokus pada respon terhadap pesaing.

Kedua, responsifitas terhadap pesaing terhadap kinerja pemasaran maupun terhadap kinerja keuangan dengan dimoderasi tensi persaingan tidak bersifat signifikan. Dapat diprediksi bahwa perusahaan yang memiliki sejarah daya saing berimbang bertemu akan memiliki persaingan yang kuat, meningkatkan tensi persaingan yang dirasakan antar perusahaan, dan saling meningkatkan kinerja perusahaan. Sedangkan dalam penelitian ini antar perusahaan yang memiliki sejarah persaingan yang dapat meningkatkan tensi persaingan tidak mempengaruhi kinerja perusahaan satu dengan yang lain.

Ketiga, responsifitas terhadap pesaing berpengaruh terhadap kinerja pemasaran maupun terhadap kinerja keuangan dengan dimoderasi slack resources berpengaruh secara signifikan. Hal ini berarti slack resources pada organisasi atau perusahaan mempengaruhi kebijakan perusahaan dalam hal penigkatan kinerja pemasaran dan keuangan. Dalam penelitian ini perusahaan dengan slack resources tinggi cenderung enggan menggunakan sumberdayanya atau enggan untuk beresiko dibandingkan dengan perusahaan yang memiliki slack resources rendah. slack yang tinggi menyebabkan keengganan risiko, yang mengakibatkan rendahnya eksplorasi, pasif dalam respon organisasi, dan peningkatan motivasi untuk memanfaatkan kompetensi melalui eksploitasi.

Berikut ini adalah beberapa implikasi bagi pemasar. Pertama, persaingan yang dianggap vital oleh perusahaan distributor pulsa elektrik bukan terjadi pada cabang yang berdekatan melainkan persaingan pada sisi produk. Penelitian ini menunjukkan persaingan pada sisi produk sebaiknya lebih diperhatikan dibandingkan dengan persaingan yang dikarenakan cabang yang berdekatan dengan pesaing, hal ini disebabkan oleh tidak adanya batasan wilayah bagi para agen pulsa untuk memilih perusahaan distributor pulsa yang dapat memberikan produk dan layanan terbaik dan ketersedian bank untuk transfer pengisian 
saldo yang disediakan oleh perusahaan. Perusahaan server distributor pulsa elektrik sebaiknya lebih fokus pada produk dengan cara memperbaiki kualitas produk dan pelayanan, memberikan harga yang bersaing, menambahkan fasilitas lain selain menjual pulsa seperti pembelian token listrik, dan perusahaan juga harus lebih peka terhadap strategi pemasaran seperti biaya pendaftaran gratis maupun penyebaran brosur yang dilakukan oleh perusahaan pesaing untuk dapat mempertahankan pasar yang dimiliki. Kedua, slack resources yang tinggi menyebabkan keengganan risiko, yang mengakibatkan rendahnya eksplorasi, pasif dalam respon organisasi, dan peningkatan motivasi untuk memanfaatkan kompetensi melalui eksploitasi (Levinthal \& March, 1993). Perspektif ini menunjukan bahwa organisasi dengan tingkat sumberdaya rendah lebih mungkin untuk mengeksplorasi, terutama ketika beroperasi di lingkungan yang kompetitif (Katila \& Shane, 2005). Hal ini menunjukan perusahaan distributor pulsa elektrik dengan kelonggaran sumberdaya atau slack resources tinggi memiliki tingkat responsifitas terhadap pesaing yang cukup rendah, hal ini dikarenakan adanya pembatasan wilayah yang dilakukan oleh pihak operator telekomunikasi yang mengakibatkan perusahaan enggan untuk menggunakan sumberdayanya, untuk itu perusahaan dengan kelonggaran sumberdaya yang cukup tinggi sebaiknya memfokuskan sumber dayanya pada wilayah yang disediakan, dan bersaing untuk mempertahankan atau merebut pasar pada wilayah tersebut.

Selain implikasi bagi pemasar, penelitian ini juga memiliki implikasi akademis sebagai berikut: Pertama, penelitian ini menunjukan bagaimana perusahaan akan merespon pesaing dan meningkatkan kinerja perusahaan (Porter, 1980; Smith dkk., 1991). Kedua, perusahaan dengan slack resources tinggi cenderung enggan untuk beresiko, dan rendah dalam hal eksplorasi, peningkatan motivasi, dan kompetensi melalui eksplorasi (Levinthal \& March, 1993) sedangkan perusahaan dengan slack resources rendah lebih mungkin untuk mengeksplorasi, terutama ketika beroperasi di lingkungan yang kompetitif (Katila \& Shane, 2005). Ketiga, responsifitas terhadap pesaing terhadap kinerja perusahaan dengan dimoderasi tensi persaingan tidak bersifat signifikan. Penelitian ini menunjukan rivalitas yang terjadi anatar perusahaan server distributor pulsa tidak terkait dengan daya saing bersejarah pertarungan antar perusahaan dan tidak meningkatkan tensi persaingan yang dirasakan dan meningkatkan kinerja perusahaan.

Meskipun penelitian ini telah didesain sebaik mungkin, namun masih terdapat beberapa kelemahan. Penelitian ini hanya menjadikan perusahaan distributor pulsa sebagai obyek penelitian. Meskipun internal validity dari hasil penelitian ini tercukupi dengan baik, namun external validity kurang. Untuk itu, penelitian selanjutnya perlu memperluas konteks industry lain yang akan digunakan sehingga external validity dapat ditingkatkan. Kedua, slack resources dalam penelitian ini hanya dioperasionalkan melalui 2 ukuran kategori, yakni sedang dan berlebih. Penelitian selanjutnya dapat menggunakan pengukuran yang dapat dijadikan proxy yang lebih baik, misalnya rasio keuangan, bilamana perusahaan yang digunakan adalah perusahaan publik. Penggunaan perusahaan publik juga akan memudahkan penggunaan data-data yang terkait dengan perusahaan dalam operasionalisasi variabel penelitian yang digunakan, sehingga hasil penelitian akan lebih robust, valid, dan reliabel. 


\section{DAFTAR PUSTAKA}

Aaker, David A. 1998. Strategic Market Management. New York: John Willey \& Sons, Inc.

Adler, P. S., \& Kwon, S. W. 2002. Social capital: Prospects for a new concept. Academy of Management Review, 27: 17-40.

Aiken, L. S., \& West, S. W. 1991. Multiple regression: Testing and interpreting interactions, London: Sage.

Bain, J. 1956. Barriers to new competition. Cambridge, MA: Harvard University Press.

Barney, J. B. 1991. Firm resources and sustained competitive advantage. Journal of Management, 17: 99-120.

Barney, J. B., \& Hansen, M. H. 1994. Trustworthiness as a source of competitive advantage. Strategic Management Journal, 15: 175-190.

Baum, J. A. C., \& Korn, H. J. 1996. Competitive dynamics of interfirm rivalry. Academy of Management Journal, 39: 255-291.

Baum, J. A., \& Korn, H. J. 1999. Dynamics of dyadic competitive interaction. Strategic Management Journal, 20: 251-278.

Baum, J. Robert and Stefan Wally. 2003. Strategic Decision Speed and Firm Performance. Strategic Management Journal, 24 (11), 1107-1 129.

Brehm, J. W., Wright, R. A., Solomon, S., Silka, L., \& Greenberg, J. 1983. Percieve difficulty, energization, and the magnitudeof goal valence. Journal of Experimental Social Psycology, 19(1), 21-48.

Chaplin. Peny. 1985. Dictionary of Psychology. Laurel.

Chattopadhyay, P., Glick, W. H., \& Huber, G. P. 2001. Organizational actions in response to threats and opportunities. Academy of Management Journal, 44: 937-955.

Chen, M.-J., \& MacMillan, I. C. 1992. Non response and delayed response to competitive moves: The rules of competitor dependence and action irreversibility. Academy of Management Journal, 35: 539-570.

Chen, M.-J., \& MacMillan, I. C. 1993. An Exploration of the "Expertness" of Outside Informants. Academy of Management Journal (Special Research Forum on Methodology), 36: 1614-1632.

Chen, M.-J. 1996. Competitor analysis and inter-firm rivalry: Towards a theoretical integration. Academy of Management Review, 21: 100-134.

Chen, M-J, Su, K-S, \& Tsai, W. 2007. Competitive tension: The awareness-motivation capability perspective. Academy of Management Journal, 50, 101-118.

Cohen, Jacob, Patricia Cohen, Stephen G. West, and Leona S. Aiken. 2003. Applied Multiple Regression/Correlation Analysis for the Behavioral Sciences. 3d ed. Mahwah, NJ: Lawrence Erlbaum Associates.

Cool, K., \& Schendel, D. 1987. Strategic group information and performance: The case of the U.S. pharmaceutical industry, 1963-1982. Management science, 33: 1102-1124

Danim, Sudarwan. 1997. Pengantar Studi Penelitian Kebijakan. Edisi Pertama. Cetakan Pertama, Jakarta: Bumi Aksara.

Deaux, K., et al. 1993. Social psychology in the 90s. Sixth Edition. Pasific Grove, CA: Brooks/Cole Publishing.

Dutton, J. E., \& Jackson, S. E. 1987. Categorizing strategic issues: Links to organizational action. Academy of Management Review, 12: 76-90.

Dutton, J. E., \& Duncan, R. B. 1987. The creation of momentum for change through the process of strategic issue diagnosis. Strategic Management Journal, 8: 279-295.

Ferrier, W. J. 2001. Navigating the competitive landscape. The drivers and consequences of competitive aggresivness. Academy of Management Journal, 44: 858-877.

Fiegenbaum, A., \& Thomas, H. 1988. Attitudes toward risk and the risk-return paradox: Prospect theory explanations. Academy of Management Journal, 31: 85-106. 
Gatignon, Hubert, Thomas S. Robertson and Adam Fein. 1997. Incumbent Defense Strategies Against Innovative Entry. International Journal of Research in Marketing, 14, 2, 163176.

Gimeno, J. 1999. Reciprocal threats in multi market rivalry: Staking out "spheres of influence" in the U.S. airlines industry. Strategic Management Journal, 20: 101-128.

Greve, H. R. 2003. A behavioral theory of R\&D expenditures and innovations: Evidence from shipbuilding. Academy of Management Journal, 46: 685-702.

http://teknologi.vivanews.com/news/read/273848-pembeli-pulsa-fisik-operator-hanya-2persen

http://www.tribunnews.com/201 1/04/03/pelanggan-ponsel-di-indonesia-capai-240-juta

Jayachandran, S., Hewett, K. and Kaufman, P. 2004. Customer response capability in a sense-and-respond era: The role of customer knowledge process. Academy of Marketing Science, 32 (3), 219-233.

Katila, R., \& Shane, S. 2005. When does slack of resources make new firms innovative? Academy of Management Journal, 48: 814-829.

Kementerian Komunikasi dan Informasi (2012). Data Statistik ICT. http://statistik.kominfo.go.id/site/data?idtree $=217$ \&iddoc=607. Diakses tanggal 24 April 2012.

Kiduff, Gavin J. dkk. 2010. The psychology of rivalry: ARelationally Dependent Analysis of Competition. Academy of Management Journal, vol.53 No.5, 943-969.

Kirca, A. H., Jayachandran, S. , \& Bearden, W. 2005. Market orientation: a meta-analytic review and assessment of its antecedents and impact on performance. Journal of Marketing, 69 (2), 24-41.

Kohli, Ajay K. and Bernard J. Jaworski. 1990. Market Orientation: The Construct, Research Propositions, and Managerial Implications. Journal of Marketing, 54 (April), 1- 18.

Kumar, Kamalesh, Ram Subramanian, and Charles Yauger. 1998. Examining the Market Orientation-Performance Relationship: A Context-Specific Study. Journal of Management, 24 (2), 201-233.

Kraatz, M. S. \& Zajac, E. J. 2001. How organizational resources affect strategic change and performance in turbulent environments: Theory and evidence. Organization Science, 12: 632-657.

Kuncoro. Mudrajad. 2006. Strategi Bagaimana Meraih Keunggulan Kompetitif. Penerbit Erlangga, Jakarta

Levinthal, D., \& March, J. 1993. The myopia of learning. Strategic Management Journal, 14: 95-112.

Malhotra, V. M. 1999. Making Concrete "Greener" with Fly Ash. ACl Concrete International, 21.

Maltz, Elliot and Ajay K. Kohli. 1996. Market Intelligence Dissemination Across Functional Boundaries. Journal of Marketing Research, 33 (February), 47-61.

Mishina, Y., Pollock, T. G., \& Porac, J. F. 2004. Are more resources always better for growth? Resource stickiness in market and product expansion. Strategic Management Journal, 25: 1179-1197.

Moorman, Christine and Roland T. Rust. 1999. The Role of Marketing. Special millennium issue of the Journal of Marketing, 63 (Special Issue), 180-197.

Mustafa, Husen. 2000. Teknik Sampling. Ghalia. Jakarta.

Narver, J. C. \& Slater, S. F. 1990. The Effect of a Market Orientation on Business Profitability. Journal of Marketing, 54 (4), pp. 20-35.

Nohria, N., \& Gulati, R. 1996. Is slack good or bad for innovation? Academy of Management Journal, 39: 1245-1264.

O'Brien, J. P. 2003. The capital structure implications of pursuing a strategy of innovation. Strategic Management Journal, 24: 415-431.

Peteraf, M. A., \& Bergen, M. A. 2003. Scanning competitive landscapes: A market-based and resource-based framework. Strategic Management Journal, 24: 1027. 